\title{
A dilution approach to quantify the production of dissolved dimethylsulphoniopropionate and dimethyl sulphide due to microzooplankton herbivory
}

\author{
Stephen D. Archer ${ }^{1, *}$, Claire E. Stelfox-Widdicombe ${ }^{1}$, Peter H. Burkill ${ }^{1}$, Gillian Malin ${ }^{2}$ \\ ${ }^{1}$ Plymouth Marine Laboratory, Prospect Place, Plymouth PL1 3DH, United Kingdom \\ ${ }^{2}$ School of Environmental Sciences, University of East Anglia, Norwich NR4 7TJ, United Kingdom
}

\begin{abstract}
A dilution approach for quantifying the grazing-mediated production of dissolved dimethylsulphoniopropionate (DMSPd) and dimethyl sulphide (DMS) was tested using laboratory cultures and in natural marine waters. We attempted to make simultaneous estimates of microzooplankton grazing rate and grazing-mediated production of DMS and DMSPd. In the laboratory, the dinoflagellate Oxyrrhis marina grazed on the prymnesiophyte Isochrysis galbana at a rate equivalent to a turnover of $57 \% \mathrm{~d}^{-1}$ of the standing stock. Three experiments using natural waters are presented; 1 in the southern North Sea on 13 April 1998 and 2 in the Iceland Basin on 27 June and 4 July 1998. In all cases there was significant microzooplankton grazing with a turnover of $20 \% \mathrm{~d}^{-1}$ of the chlorophyll $a$ in the southern North Sea on 13 April and 19 and $15 \% \mathrm{~d}^{-1}$ of the nanophytoplankton on 27 June and 4 July in the Iceland Basin, respectively. Production rates of DMS, DMSPd and DMS+DMSPd due to grazing were calculated from the slope of the regression between algal-specific production and the level of dilution, a proxy of the grazing pressure. DMS+DMSPd production rates due to microzooplankton grazing of $31 \pm 6,28 \pm 2,14 \pm 3$ and $10 \pm 1 \mathrm{nM} \mathrm{d}^{-1}( \pm \mathrm{SE})$, were measured in the laboratory and on 13 April, 27 June and 4 July. These values represent a conversion of 19, 14, 15 and $9 \% \mathrm{~d}^{-1}$ of the standing stock of DMSPp to DMS+DMSPd. The potential impact of bacterial metabolism of DMS and DMSPd on estimates of grazing mediated production together with other competing production/loss processes are discussed. We suggest that in marine surface waters microzooplankton grazing plays an important role in the generation of the dissolved pool of DMS+DMSPd.
\end{abstract}

KEY WORDS: Dimethyl sulphide · Dimethylsulphoniopropionate $\cdot$ DMS · DMSP · Grazing · Microzooplankton $\cdot$ Bacteria

\section{INTRODUCTION}

Dimethyl sulphide (DMS) is a major component of the global sulphur cycle (Lovelock et al. 1972). Marine emissions of DMS play an important role in the remote marine atmosphere, where the oxidation products of DMS influence the formation and acidity of aerosols, affecting cloud formation over the oceans and planetary albedo (Bates et al. 1987, Charlson et al. 1987,

*E-mail: stda@pml.ac.uk
Andreae 1990). The concentration of DMS in marine surface waters is thought to be determined by an intricate web of microbial processes. Current research efforts are focussed on elucidating the key processes that control DMS concentrations in natural waters, as a step towards developing predictive models of DMS emission.

The main precursor of atmospheric DMS is 3dimethylsulphoniopropionate (DMSP), which is produced by some marine phytoplankton species (Keller et al. 1989). In laboratory cultures, the highest intracellular concentrations of DMSP are found in cells that 
belong to the classes Prymnesiophyceae and Dinophyceae (Keller et al. 1989). Distributions of particulate DMSP (DMSPp) in natural waters are now thought to reflect these interspecific differences, with particularly high DMSPp concentrations correlated with the abundance of prymnesiophytes such as Phaeocystis sp. and coccolithophores and with a variety of dinoflagellates (e.g. Barnard et al. 1984, Holligan et al. 1987, Turner et al. 1988, 1996, Malin et al. 1993, Matrai \& Keller 1993).

DMS can be formed in marine waters via enzymatic cleavage of DMSP to DMS and acrylic acid. Such enzymes have been characterised from a heterotrophic dinoflagellate (Kadota \& Ishida 1968), phytoplankton (Stefels \& Dijkhuizen 1996, Steinke et al. 1998), bacteria (e.g. de Souza \& Yoch 1995), a marine fungus (Bacic $\&$ Yoch 1998) and certain species of macroalgae (e.g. de Souza et al. 1996). Following the discovery by Sieburth (1960) that DMSP breakdown in krill stomachs resulted in acrylic acid formation, several laboratory studies have demonstrated that grazing by zooplankton enhances DMS production (Dacey \& Wakeham 1986, Malin et al. 1994, Christaki et al. 1996, Wolfe \& Steinke 1996). Field studies also suggest that grazing is a key route by which dissolved DMSP (DMSPd) and DMS are produced (Belviso et al. 1990, Leck et al. 1990, Holligan et al. 1993, Christaki et al. 1996, Daly \& DiTullio 1996). However, grazing does not always result in the production of DMS (Wolfe et al. 1994, Kwint et al. 1996). Furthermore, disruption of phytoplankton cells by grazing may mix DMSP and algal DMSP lyase enzymes, possibly acting as a defence mechanism by producing high concentrations of acrylic acid in the food vacuoles of heterotrophic protists (Wolfe et al. 1997).

Microzooplankton are generally dominated by heterotrophic protists, and these organisms are important grazers of phytoplankton in the sea. Estimates of microzooplankton grazing impact indicate that 20 to $>100 \%$ of primary production can be consumed each day (e.g. Gifford 1988, Burkill et al. 1993, Verity et al. 1996) and they may, therefore, be important in determining the fate of phytoplankton DMSP. The dilution technique (Landry \& Hassett 1982) is widely used to determine the grazing impact of microzooplankton on phytoplankton. The technique involves incubation of a series of water samples diluted with increasing amounts of filtered water to sequentially reduce the grazing of microzooplankton on phytoplankton. Microzooplankton grazing rate is calculated from the slope $(g)$ of the relationship between net phytoplankton growth rate $(r)$ and the fraction of unfiltered water. The fraction of whole water is used as a proxy of the relative grazing activity of the microzooplankton. The specific growth rate of the phytoplankton $(k)$ is estimated from the net growth rate extrapolated to a fraction of whole water $=0$. The dilution technique assumes that phytoplankton growth is exponential and independent of the dilution, while phytoplankton mortality is density-dependent and proportional to the microzooplankton concentration. Critical reviews of the dilution approach have been made by Gallegos (1989), Chavez et al. (1991), Evans \& Paranjape (1992), Landry et al. (1995) and Dolan et al. (2000).

Despite the potential importance of microzooplankton herbivory in determining the fate of phytoplankton DMSP and evidence that grazing transforms phytoplankton DMSP to DMS/DMSPd, quantitative information on grazing-mediated production in natural waters is limited. The dilution technique has been used to determine ammonium uptake and regeneration rates (Neuer \& Franks 1993) and to quantify external and internal nutrient pools and nutrient supply through remineralisation (Andersen et al. 1991). In this study we investigated whether the approach can also be used to determine the production of DMS/DMSPd due to microzooplankton grazing, as DMSPp may be released from phytoplankton cells as either DMSPd or DMS. Additionally, DMSPd may be cleaved to DMS by extracellular lyase enzymes derived from a variety of sources, including bacteria and algae. Hence, we examined the dynamics of DMS, DMSPd and the combined pool of DMS+DMSPd in relation to grazing rates in a series of dilution experiments using laboratory cultures and natural populations from 2 regions in 1998.

\section{MATERIALS AND METHODS}

Experimental strategy. The objective of the experiments was to quantify DMS/DMSPd production/loss in relation to a gradient of grazing pressure produced by the dilution technique. Measurements of phytoplankton net growth over the course of dilution incubations were combined with measurements of the change in DMS and DMSPd concentration. As bacteria may influence the levels of DMS and DMSPd (e.g. Kiene \& Bates 1990, Ledyard \& Dacey 1996), bacterial abundance and net growth rate were determined during the dilution incubations. In addition, the rate of DMS consumption in natural waters was measured using dimethyl disulphide (DMDS) as an inhibitor. Details of the experimental design of the dilution experiments and the location and depth of the experiments conducted in natural waters are summarised in Table 1.

Laboratory experiments. Stock cultures of the prymnesiophyte Isochrysis galbana (PCC I) and heterotrophic dinoflagellate Oxyrrhis marina (PCC) were grown in filtered, autoclaved seawater enriched with f/2 nutrients (Guillard \& Ryther 1962). Cultures were incubated in continuous light at approximately $100 \mu \mathrm{E}$ 
Table 1. Location, dates and depths at which water samples were collected and the incubation format for DMS-dilution experiments. Water used to produce the filtrate on 27 June and 4 July, for incubations in which DMS and DMSPd production was measured was collected from $100 \mathrm{~m}$. On these dates, phytoplankton growth rates were also determined in parallel dilution experiments using diluent prepared from surface waters. nm: not measured

\begin{tabular}{|c|c|c|c|c|c|}
\hline \multirow{2}{*}{$\begin{array}{l}\text { Expt, } \\
\text { Date }\end{array}$} & \multirow[t]{2}{*}{ Location } & \multirow{2}{*}{$\begin{array}{l}\text { Depth } \\
\text { (m) }\end{array}$} & \multicolumn{3}{|c|}{ Incubations: no. of bottles $\times$ vol (l) } \\
\hline & & & $\begin{array}{l}\text { Grazing rate } \\
\text { determination }\end{array}$ & $\begin{array}{l}\text { DMS(Pd) } \\
\text { monitored }\end{array}$ & $\begin{array}{l}\text { DMS uptake } \\
\text { measured }\end{array}$ \\
\hline \multicolumn{6}{|c|}{ Laboratory experiment } \\
\hline 22 Oct 1997 & - & - & $\longrightarrow$ & - & $\mathrm{nm}$ \\
\hline \multicolumn{6}{|l|}{ North Sea } \\
\hline 13 Apr 1998 & $\begin{array}{l}53^{\circ} 07^{\prime} 00^{\prime \prime} \mathrm{N} \\
04^{\circ} 32^{\prime} 16^{\prime \prime} \mathrm{E}\end{array}$ & 3 & $12 \times 2.3$ & $5 \times 1.1$ & $4 \times 0.5$ \\
\hline \multicolumn{6}{|l|}{ Iceland Basin } \\
\hline 27 Jun 1998 & $\begin{array}{l}60^{\circ} 25^{\prime} 54^{\prime \prime} \mathrm{N} \\
20^{\circ} 39^{\prime} 37^{\prime \prime} \mathrm{W}\end{array}$ & $\begin{array}{c}4 \\
(100)\end{array}$ & $12 \times 2.3$ & 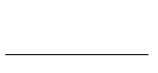 & $4 \times 0.5$ \\
\hline \multicolumn{6}{|l|}{ Iceland Basin } \\
\hline 4 July 1998 & $\begin{array}{l}59^{\circ} 20^{\prime} 22^{\prime \prime} \mathrm{N} \\
21^{\circ} 44^{\prime} 43^{\prime \prime} \mathrm{W}\end{array}$ & $\begin{array}{c}3 \\
(100)\end{array}$ & $5 \times 2.3$ & & $4 \times 0.5$ \\
\hline
\end{tabular}

$\mathrm{m}^{-2} \mathrm{~s}^{-1}$ at $15^{\circ} \mathrm{C}$ in glass conical flasks. One day before the experiment, both cultures were combined to produce an experimental stock with a prey to predator ratio of approximately 100:1. For the experiment, a portion of the stock culture was filtered (GF/C nominal pore size $1.2 \mu \mathrm{m}$ ) and the filtrate and remaining stock culture used to produce a dilution series in $250 \mathrm{ml} \mathrm{Nal-}$ gene polycarbonate bottles. Bottles were filled leaving minimal headspace, capped and rotated gently by hand prior to subsampling at $t_{0}$ and $t_{20}$ hours, taking $4 \times 1 \mathrm{ml}$ for cell enumeration (prey, predator and bacteria) and $5 \mathrm{ml}$ for $\mathrm{DMS}(\mathrm{P})$ analyses. Cell numbers were determined by analytical flow cytometry (AFC).

Experiments in natural waters. The timing and location of experiments carried out in natural waters focussed on episodes of significant DMS production. The first cruise, from 6 April to 29 April, took place in the southern North Sea aboard the RV 'Pelagia' and formed part of the European Union funded ESCAPE (Entangled Sulphur and CArbon cycles in Phaeocystis dominated Ecosystems) programme. The highest concentrations and emission rates of DMS in the southern North Sea occur in May/June (e.g. Turner et al. 1996) as a result of the spring bloom of Phaeocystis sp. (Stefels et al. 1995, van Duyl et al. 1998). The second cruise occurred between 6 June and 8 July, in the Iceland Basin aboard the RRS 'Discovery' and was part of the UK Natural Environment Research Council (NERC)-funded ACSOE (Atmospheric Chemistry Studies in the Oceanic Environment) programme. In the Iceland Basin, mesoscale blooms of coccolithophores in June/July play a significant role in the emission of DMS to the atmosphere (Holligan et al. 1993, Malin et al. 1993).

The procedures for the dilution experiments in natural waters were based on the protocol of Landry
(1993). This was modified to incorporate additional parallel incubations in which changes in the concentrations of DMS and DMSPd were monitored and rates of bacterial consumption of DMS were determined (Table 1).

Preparation of filtered water: Prior to each experiment, filter capsules (0.2 $\mu \mathrm{m}$ pore size Gelman Suporcapsule filters) and silicon tubing were soaked in 10\% HCl-Milli-Q water, rinsed with Milli-Q water, and the first several litres of filtered seawater discarded. Disruption of cells during filtration procedures is known to affect estimates of ${ }^{14} \mathrm{C}$ uptake by phytoplankton (e.g. Goldman \& Dennett 1985) and could therefore alter the concentrations of DMS and DMSPd between filtered and unfiltered water when preparing dilution experiments. Thus, natural water samples were filtered slowly $\left(<0.51 \mathrm{~min}^{-1}\right)$ through the capsule filters. On a number of occasions in both the North Sea and Iceland Basin, the filtration process resulted in increased concentrations of both DMS and DMSPd in the filtered water. In addition, concentrations of DMS in the filtered water continued to increase when incubated, possibly as a result of the release of DMSP lyase enzymes during the filtration procedure that continued to convert the DMSPd to DMS. On other dates, including the North Sea experiment reported here, this did not occur. It was unclear what caused the variation in levels of DMS/DMSPd release due to the filtration procedure between dates. However, to avoid such problems, in the 2 experiments from the Iceland Basin, filtered water was prepared from water collected from $100 \mathrm{~m}$ for incubations in which DMS(Pd) measurements were made. This water contained relatively low phytoplankton abundance and low DMS and DMSPd concentrations. Filtered water from the same depth as the undiluted water was used to dilute a parallel series of 
incubations to act as a control for the determination of growth and grazing rates (Table 1).

Incubations: Undiluted water was gently passed through a $200 \mu \mathrm{m}$ gauze to remove mesozooplankton as it was added to each incubation bottle. All incubations were carried out in the same flow-through, ondeck incubator flushed with seawater and covered with an acrylic screen and 2 sheets of Perspex to simulate a $55 \%$ PAR (400 to $700 \mathrm{~nm}$ ) light level. The numbers and volumes of incubation bottles for each experiment are outlined in Table 1. All experiments were incubated for approximately $24 \mathrm{~h}$ except on the 4 July when the incubation was continued for approximately $48 \mathrm{~h}$.

Measurement of microzooplankton biomass: Samples collected at the start of experiments were fixed in $1 \%$ acid Lugol's iodine and analysed in the laboratory by inverted microscopy (Utermöhl 1958). The size and volume of heterotrophic microzooplankton were calculated using an image-analysis system. The carbon content of each cell was calculated using carbon:volume conversion factors of $0.14 \mathrm{pg} \mathrm{C} \mathrm{mm}^{-3}$ for dinoflagellates

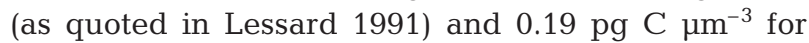
ciliates (Putt \& Stoecker 1989).

Determination of phytoplankton net growth rate: In the North Sea experiment, phytoplankton growth was measured in 3 replicate 2.31 incubations at each level of dilution (Table 1). The net rate of growth of the total phytoplankton population in each bottle was determined from initial and final concentrations of chlorophyll a. Pigment concentration was measured fluorometrically using $90 \%$ acetone extracts of $0.2 \mu \mathrm{m}$ filtered water. In the Iceland Basin, nanophytoplankton growth rates were measured in parallel incubations diluted using either filtered water from $100 \mathrm{~m}$ or filtered water from near the surface (Table 1). The net growth rates of the nanophytoplankton were determined by AFC cell counts using a combination of red fluorescence (>650 nm) and $90^{\circ}$ light-scatter signals. Gravity filtration through Nuclepore filters of 2.0 and $18 \mu \mathrm{m}$ pore size was used to distinguish nanophytoplankton groups from pico- and microphytoplankton.

Determination of bacterial abundance and net growth rate: Bacterial abundance in laboratory cultures and natural waters was determined by staining with the nucleic acid dye SYBR Green I (Molecular Probes) and counting by flow cytometry (Marie et al. 1997). The net growth rate of bacteria in the dilution incubations determined from initial and final abundance, was measured from subsamples fixed with $0.1 \%$ glutaraldehyde (final concentration), frozen in liquid nitrogen and stored at $-80^{\circ} \mathrm{C}$ until analysis in the laboratory. After thawing, $5 \mu$ l of $1 \%$ SYBR Green I and $45 \mu \mathrm{l}$ of $300 \mathrm{mM}$ potassium citrate were added to a
$500 \mu \mathrm{l}$ aliquot of the fixed subsample. The abundance of heterotrophic bacteria were determined by subtracting the number of autotrophic picoplankton from the total number of stained cells discriminated using a combination of $90^{\circ}$ angle light scatter and green fluorescence in stained samples (Zubkov et al. 1998). Autotrophic picoplankton were identified and enumerated in glutaraldehyde-fixed, unstained aliquots by a combination of $90^{\circ}$ angle light scatter and red fluorescence.

Analytical flow cytometry: All flow cytometric counts were performed with a FACSort flow cytometer (Becton Dickinson, Oxford, UK) equipped with a $15 \mathrm{~mW}$ laser exciting at $488 \mathrm{nM}$ and a standard filter setup. Flow rates of the flow cytometer were calibrated routinely by measuring the changes in weight or volume (onboard ship) in samples run for differing lengths of time. Parameters were collected as logarithmic signals and graphs drawn and analysed using WinMDI freeware (J. Trotter, The Scripps Research Institute [facs.scripps.edu]).

Measurement of DMS consumption: Dimethyl disulfide (DMDS) was used as a selective inhibitor to determine DMS consumption by bacteria (Wolfe \& Kiene 1993) in the experiments conducted during the 2 field studies. The preparation of DMDS solutions and quantities of DMDS added to undiluted $500 \mathrm{ml}$ incubations differed between experiments in the North Sea and Iceland Basin. In the North Sea study, a stock solution of DMDS (Sigma) dissolved in ethanol was used to produce a final concentration of 100 nM DMDS in 2 incubations and an equal volume $(20 \mu \mathrm{l})$ of ethanol was added to 2 control incubations. In contrast, in the Iceland Basin study, DMDS was dissolved in Milli-Q water and added to 2 incubation bottles to produce a final concentration of $150 \mathrm{nM}$ DMDS. No additions were made to the 2 control incubations. DMDS incubations took place in the same on-deck incubators, in parallel to the dilution experiments. DMS consumption rates were calculated from the difference between gross DMS production calculated from DMDS addition incubations and net DMS production measured in control incubations (Kiene \& Bates 1990).

Sulphur analyses: A cryogenic purge-and-trap/gas chromatography system similar to that described by Turner et al. (1990) was used to determine DMS concentrations. A Varian 3800 gas chromatograph equipped with a pulsed flame photometric detector (PFPD) was used to analyse all samples. The analytical column used was a $30 \mathrm{~m} \times 0.53 \mathrm{~mm} \mathrm{CP}$ Sil $5 \mathrm{CB}$ from Chrompack and was operated isothermally at $60^{\circ} \mathrm{C}$. Nitrogen was the carrier gas at a flow rate of $5 \mathrm{ml}$ $\mathrm{min}^{-1}$. DMS standards for calibration were prepared from DMSP-HCl (>98\% purity; CASS, University of Groningen) in Milli-Q water to which $\mathrm{NaOH}$ was added to a final concentration of $1 \mathrm{M}$. 
Concentrations of DMS, DMSPp and DMSPd were all measured in the same aliquot of water. Water samples were filtered by gravity through GF/F (laboratory and Iceland Basin) or Millipore AP25 (North Sea) filters. The filtrate was transferred immediately to a purge chamber and sparged with nitrogen at $40 \mathrm{ml}$ $\mathrm{min}^{-1}$ for 5 to $20 \mathrm{~min}$, depending on the volume, which ranged from 2 to $10 \mathrm{ml}$. The purge gas was passed through a cold finger at $0^{\circ} \mathrm{C}$ followed by an ME Gas Dryer ${ }^{\mathrm{TM}}$ prior to entering a cryotrap consisting of a loop of $1 / 16^{\prime \prime}$ Teflon tubing maintained at $-160^{\circ} \mathrm{C}$ above liquid nitrogen. After purging, the trap was heated to $95^{\circ} \mathrm{C}$ to transfer the trapped gas to the GC. The purged filtrate was used to determine DMSPd concentrations and the filters used to determine DMSPp concentrations. Samples for DMSPp and DMSPd were hydrolysed with $\mathrm{NaOH}$ and analysed as for DMS. The detection limit of the system for DMS was approximately $50 \mathrm{pg} \mathrm{S}$. Tests of precision (coefficient of variation) for DMS measurements from triplicate 5 and $20 \mathrm{ml}$ natural water samples were 2.2 and $3.8 \%$, respectively.

Calculations: Model I regression theory (Sokal \& Rohlf 1981) was used to compute specific growth $(k)$ and mortality due to grazing $(g)$ from apparent net growth rates $(r)$ and level of dilution (fraction of whole water in the dilution treatment). Apparent net growth rate of the measured variables (Isochrysis galbana cell number, chlorophyll $a$, nanophytoplankton abundance, bacterial abundance) for each incubation bottle was calculated from initial $\left(C_{t_{0}}\right)$ and final $\left(C_{t_{1}}\right)$ concentrations after incubation time $\left(t=t_{1}-t_{0}\right)$ :

$$
r=\ln \left(C_{t_{1}} / C_{t_{0}}\right) / t
$$

The level of dilution was determined from the initial $\left(C_{t_{0}}\right)$ concentration of phytoplankton in each bottle relative to the concentration in undiluted water.

Initial and final concentrations of DMS and DMSPd were used to calculate net production rates of DMS and DMSPd for each level of dilution and the 2 rates combined to estimate a value of net DMS+DMSPd production. As the principal producers of DMSP, phytoplankton are considered to be the primary source of DMS and DMSPd. Net DMS, DMSPd and DMS+ DMSPd production rates were therefore normalised to the algal concentration in each incubation. A timeaveraged algal concentration was calculated to account for phytoplankton growth. The time-averaged algal concentration $(<C>)$ for each incubation bottle was calculated using the equation of Frost (1972), such that:

$$
<C>=C_{t_{0}}\left[\mathrm{e}^{(k-g)\left(t_{1}-t_{0}\right)}-1\right] /\left(t_{1}-t_{0}\right)(k-g)
$$

where $C$ refers to the concentration of Isochrysis galbana, chlorophyll $a$ or nanophytoplankton, and $k$ and $g$ are values determined from the regression analysis of each dilution experiment. Values for $g$ were scaled in proportion to $C_{t_{0}}$ for each level of dilution, in accordance with 1 of the assumptions of the dilution approach. The mean algal concentration $(<C>)$ expressed as a fraction of $\langle C\rangle$ in the undiluted incubations (fraction of whole water $=1$ ), was used to calculate an algalspecific production of DMS, DMSPd and DMS+DMSPd (nM algal fraction $\left.{ }^{-1} \mathrm{~d}^{-1}\right)$.

\section{RESULTS}

The initial concentrations of DMSPp, DMS, DMSPd and biological composition of the waters used for the dilution experiments are shown in Table 2.

\section{Laboratory experiment}

The experiment using laboratory cultures confirmed that Oxyrrhis marina grazes voraciously on Isochrysis galbana. The growth rate of $I$. galbana $\left(k=0.67 \mathrm{~d}^{-1}\right)$ was equivalent to almost 1 doubling $\mathrm{d}^{-1}$ (Table 3 ). I. galbana concentrations were an order of magnitude lower than those generally achieved on reaching stationary phase $\left(>10^{5}\right.$ cell ml $\left.{ }^{-1}\right)$ under the same conditions, suggesting that nutrients were not depleted. The rate of mortality due to grazing $(g)$ was $0.85 \mathrm{~d}^{-1}$, equivalent to a turnover of I. galbana cells of $57 \% \mathrm{~d}^{-1}$ (Table 3).

The initial concentrations of DMS and DMSPd were similar at all dilution levels (Table 4). This suggests that the DMS and DMSPd content of the diluent was not perturbed significantly by the filtration process per se. The concentration of DMS increased in each incubation, DMSPd concentration decreased in each incubation, whilst the combined DMS and DMSPd production/loss values were highest with increasing grazing pressure. However, a net loss of DMS+DMSPd occurred in the most dilute incubation (Table 4).

Bacterial abundance was $1.3 \times 10^{5}$ cells ml $^{-1}$ in the undiluted culture (Table 2). Approximately $50 \%$ of the bacteria passed through the GF/C filter, resulting in $0.7 \times 10^{5} \mathrm{cell} \mathrm{ml}^{-1}$ in the filtrate. The net growth rate of bacteria was highest in the more dilute samples, reaching $2.5 \mathrm{~d}^{-1}$, equivalent to 3.75 doublings $\mathrm{d}^{-1}$, in the filtered water. (For the Model 1 regression of the relationship between net growth rate and level of dilution see Table 5.)

\section{In situ studies}

\section{North Sea}

The experiment carried out in the southern North Sea coincided with the development of the spring phy- 
Table 2. Properties of the water used for dilution experiments. Concentrations of DMSPp, DMS, DMSPd, chlorophyll a (chl a), microzooplankton (MZP) biomass and bacterial abundance were measured in undiluted water at the beginning of the incubations. The abundance of Isochrysis galbana $(\mathrm{Ig})$ and Oxyrrhis marina $(\mathrm{Om})$ are given for the laboratory experiment

\begin{tabular}{|c|c|c|c|c|c|c|c|}
\hline $\begin{array}{l}\text { Expt, } \\
\text { Date }\end{array}$ & $\begin{array}{l}\text { Temp. } \\
\left({ }^{\circ} \mathrm{C}\right)\end{array}$ & $\begin{array}{l}\text { DMSPp } \\
\text { (nM) }\end{array}$ & $\begin{array}{l}\text { DMS } \\
(\mathrm{nM})\end{array}$ & $\begin{array}{l}\text { DMSPd } \\
(\mathrm{nM})\end{array}$ & $\begin{array}{c}\mathrm{Chl} \mathrm{a} \\
\left(\mathrm{mg} \mathrm{m}^{-3}\right)\end{array}$ & $\begin{array}{c}\text { MZP biomass } \\
\left(\mathrm{mg} \mathrm{C} \mathrm{m}^{-3}\right)( \pm \mathrm{SD})\end{array}$ & $\begin{array}{c}\text { Bacteria } \\
\left(10^{5} \text { cells ml }{ }^{-1}\right)( \pm \mathrm{SD})\end{array}$ \\
\hline \multicolumn{8}{|c|}{ Laboratory experiment } \\
\hline 22 Oct 1997 & 15 & 163 & 21.4 & 63.2 & $12260 \mathrm{Ig} \mathrm{ml}^{-1}$ & $236 O \mathrm{Om} \mathrm{ml} \mathrm{l}^{-1}$ & 1.33 \\
\hline \multicolumn{8}{|l|}{ North Sea } \\
\hline 13 Apr 1998 & 8 & 202 & 9.9 & 11.7 & 11.8 & $36.1 \pm 0.5$ & $4.19 \pm 0.68$ \\
\hline \multicolumn{8}{|l|}{ Iceland Basin } \\
\hline 27 Jun 1998 & 11 & 93 & 8.6 & 44.0 & 1.4 & $21.9 \pm 0.0$ & $13.2 \pm 0.00$ \\
\hline \multicolumn{8}{|l|}{ Iceland Basin } \\
\hline 4 Jul 1998 & 12 & 125 & 8.0 & 32.6 & 1.4 & $25.3 \pm 4.9$ & $23.1 \pm 0.10$ \\
\hline
\end{tabular}

toplankton bloom in highly mixed nearshore waters. The water contained high chlorophyll a and DMSPp concentrations (Table 2) and large numbers of diatoms and colonies of Phaeocystis sp. Large heterotrophic dinoflagellates (mean size $>5 \mathrm{ng} \mathrm{C} \mathrm{cell}^{-1}$, mean abundance 3000 cell $\mathrm{l}^{-1}$ ) dominated the biomass of the microzooplankton communities, whilst relatively small ( $<1.0 \mathrm{ng} \mathrm{C}$ cell $^{-1}$ ) oligotrich ciliates were the most

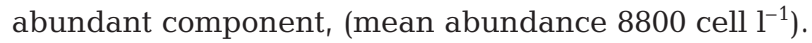

Microzooplankton grazing rates calculated from changes in chlorophyll a concentration, represented $20 \% \mathrm{~d}^{-1}$ of the initial standing stock (Table 3 ). In contrast, the specific growth rate of the phytoplankton community was low (Table 3). Nutrient concentrations measured in the water sampled for the dilution experiment were 10.80 $\mu \mathrm{M}$ nitrate, $0.58 \mu \mathrm{M}$ ammonium, $0.02 \mu \mathrm{M}$ phosphate and $0.20 \mu \mathrm{M}$ silicate (L. Villerius \& J. Stefels unpubl. data). The relationship between fraction of whole water and net growth rate produced a highly significant Model I regression (Table 3), suggesting that nutrient limitation if present was consistent between levels of dilution and that estimates of $g$ and $k$ (Table 3 ) are reasonable.
Initial DMS and DMSPd concentrations were similar in filtered and unfiltered water, again confirming minimal perturbation due to the filtration process (Table 4). DMS concentrations increased in all the incubations with the highest DMS production in the least dilute incubations. DMSPd showed a similar trend, although DMSPd concentrations decreased in the 2 more dilute incubations. A net DMS+DMSPd production occurred in all incubations except in the most dilute (Table 4). The rate of bacterial growth $(k)$, almost 1 doubling $\mathrm{d}^{-1}$, and slope of the regression $(g)$ were closely matched and higher than that of the phytoplankton community (Table 5).

\section{Iceland Basin}

In the Iceland Basin, water was sampled from the outer edge of a mesoscale eddy. Chlorophyll $a$ and DMSPp concentrations and the microbial community composition were similar in the 2 experiments (Table 2). Nanophytoplankton were an abundant component of the phyto-

Table 3. Results of dilution experiments carried out in the laboratory and natural waters of the southern North Sea and Iceland Basin. Values for grazing mortality and algal growth rate were determined from counts of Isochrysis galbana in the laboratory, chlorophyll a measurements in the North Sea and from counts of nanophytoplankton in the Iceland Basin. In the Iceland Basin, parallel incubations were diluted with filtrate from surface waters or from $100 \mathrm{~m}$, values for the latter are in parentheses. $\mathrm{p}$ is the significance of the F-ratio of the analysis of variance of the Model 1 regression of each dilution experiment

\begin{tabular}{|c|c|c|c|c|c|}
\hline $\begin{array}{l}\text { Expt, } \\
\text { Date }\end{array}$ & & $\begin{array}{l}\text { Grazing mortality } \\
\qquad(g \pm \mathrm{SE})\left(\mathrm{d}^{-1}\right)\end{array}$ & $\begin{array}{l}\text { Algal growth rate } \\
(k \pm \mathrm{SE})\left(\mathrm{d}^{-1}\right)\end{array}$ & $\mathrm{p}$ & $\begin{array}{l}\text { Initial standing stock } \\
\text { grazed }\left(\% \mathrm{~d}^{-1}\right)\end{array}$ \\
\hline \multicolumn{6}{|c|}{ Laboratory experiment } \\
\hline 22 Oct 1997 & I. galbana analyses & $0.85 \pm 0.07$ & $0.67 \pm 0.05$ & 0.11 & 57 \\
\hline \multicolumn{6}{|l|}{ North Sea } \\
\hline 13 Apr 1998 & Chlorophyll $a$ analyses & $0.23 \pm 0.02$ & $0.09 \pm 0.01$ & $\leq 0.01$ & 20 \\
\hline \multicolumn{6}{|l|}{ Iceland Basin } \\
\hline 27 Jun 1998 & Nanophytoplankton analyses & $\begin{array}{c}0.21 \pm 0.04 \\
(0.14 \pm 0.02)\end{array}$ & $\begin{array}{c}0.24 \pm 0.03 \\
(0.26 \pm 0.02)\end{array}$ & $\begin{array}{l}\leq 0.01 \\
(\leq 0.01)\end{array}$ & 19 \\
\hline $\begin{array}{l}\text { Iceland Basin } \\
\quad 4 \text { Jul } 1998\end{array}$ & Nanophytoplankton analyses & $\begin{array}{c}0.16 \pm 0.04 \\
0.16+0.05)\end{array}$ & $0.35 \pm 0.03$ & 0.03 & 15 \\
\hline
\end{tabular}


Table 4. Values of the level of dilution (proportion of natural water in the dilution treatment), initial $\left(t_{0}\right)$ concentrations of DMS and DMSPd (nM) and production/ loss rates of DMS, DMSPd and DMS+DMSPd $\left(\mathrm{nM} \mathrm{d}^{-1}\right)$ in incubations in which DMS and DMSPd dynamics were measured. Values of DMS dynamics are from single incubations at each level of dilution carried out in parallel to the main dilution incubations, except on 27 June, when measurements (mean \pm SD) were from 3 incubations at each level of dilution (see Table 1)

\begin{tabular}{|c|c|c|c|c|}
\hline \multicolumn{5}{|c|}{ Laboratory experiment: 22 Oct 1997} \\
\hline Fraction whole water & 0.19 & 0.50 & 1.00 & \\
\hline$[\mathrm{DMS}] t_{0}$ & 19.4 & 21.2 & 21.4 & \\
\hline [DMSPd] $t_{0}$ & 65.4 & 64.0 & 63.2 & \\
\hline DMS production & 1.70 & 8.15 & 22.10 & \\
\hline DMSPd production & -4.30 & -5.54 & -6.11 & \\
\hline DMS+DMSPd production & -2.60 & 2.61 & 15.99 & \\
\hline \multicolumn{5}{|c|}{ North Sea: 13 Apr 1998} \\
\hline Fraction whole water & 0.14 & 0.40 & 0.65 & 1.00 \\
\hline$[\mathrm{DMS}] t_{0}$ & 9.3 & 10.3 & 11.4 & 9.9 \\
\hline [DMSPd] $t_{0}$ & 11.7 & 11.4 & 12.0 & 11.7 \\
\hline DMS production & 3.74 & 6.58 & 8.02 & 17.38 \\
\hline DMSPd production & -6.82 & -2.45 & 4.13 & 9.34 \\
\hline DMS+DMSPd production & -3.08 & 4.13 & 12.15 & 26.72 \\
\hline \multicolumn{5}{|c|}{ Iceland Basin: 27 Jun 1998} \\
\hline Fraction whole water & 0.07 & 0.39 & 0.71 & 1.00 \\
\hline$[\mathrm{DMS}] t_{0}$ & 0.8 & 2.7 & 5.3 & 8.6 \\
\hline [DMSPd] $t_{0}$ & 7.4 & 23.7 & 32.5 & 44.0 \\
\hline DMS production & $0.69 \pm 0.07$ & $1.29 \pm 0.16$ & $2.03 \pm 0.44$ & $2.42 \pm 2.10$ \\
\hline DMSPd production & $0.93(\mathrm{n}=1)$ & $-4.86 \pm 0.44$ & $-5.25 \pm 1.26$ & $-2.77 \pm 0.17$ \\
\hline DMS+DMSPd production & $1.58(\mathrm{n}=1)$ & $-3.57 \pm 0.60$ & $-3.22 \pm 1.69$ & $0.35 \pm 1.94$ \\
\hline \multicolumn{5}{|c|}{ Iceland Basin: 4 Jul 1998} \\
\hline Fraction whole water & 0.18 & 0.36 & 0.66 & 1.00 \\
\hline [DMS] $t_{0}$ & 3.3 & 6.0 & 7.3 & 8.0 \\
\hline [DMSPd] $t_{0}$ & 13.9 & 22.1 & 29.1 & 32.6 \\
\hline DMS production & -0.65 & -1.73 & -2.43 & -2.45 \\
\hline DMSPd production & -2.00 & -2.57 & -3.62 & -1.17 \\
\hline DMS+DMSPd production & -2.65 & -4.30 & -6.05 & -3.62 \\
\hline
\end{tabular}

plankton, with mean values of $2.63 \times 10^{6}$ and $2.32 \times 10^{6}$ cells $\mathrm{l}^{-1}$ in $200 \mu \mathrm{m}$ screened, undiluted water on 27 June and 4 July, respectively. In addition, large $(\geq 20 \mu \mathrm{m})$ autotrophic dinoflagellates were a notable component of the phytoplankton and may have contributed to the high
DMSPp concentrations observed (Table 2). The microzooplankton communities differed slightly in that a high abundance ( $\geq 1500$ cells $\mathrm{l}^{-1}$ ) of the tintinnid ciliate Eutintinnus sp. occurred on the 27 June but was not present on 4 July. However, heterotrophic dinoflagellates and oligotrich ciliates dominated the microzooplankton biomass in both experiments.

In the Iceland Basin, parallel dilution incubations in which the filtrate was produced either from water collected at $100 \mathrm{~m}$ or from near the surface were conducted. Water collected from 100 m elevated the concentrations of nitrate, phosphate and silicate in diluted incubations. On 27 June, values of nitrate, phosphate and silicate concentration in water from $100 \mathrm{~m}$ were 14.0, 0.89 and $6.14 \mu \mathrm{M}$, respectively, compared to $4.9,0.31$ and $0.81 \mu \mathrm{M}$ in water from $4 \mathrm{~m}$. Similarly, on 4 July, concentrations in water from $100 \mathrm{~m}$ were 11.8, 0.69 and $3.88 \mu \mathrm{M}$ for nitrate, phosphate and silicate, respectively, compared to $2.5,0.14 \mu \mathrm{M}$ and undetectable concentrations of silicate near the surface ( $\mathrm{T}$. Jickells unpubl. data). However, the rates of $k$ and estimates of $g$ were similar between incubations using $100 \mathrm{~m}$ and surface water for dilution on both dates (Table 3). Turnover rates calculated from changes in flow cytometric determination of the nanophytoplankton abundance in incu-

Table 5. Changes in the bacterial abundance during dilution experiments and estimates of DMS consumption by bacteria. The values of bacterial abundance were determined from the dilution incubations in which DMS and DMSPd production was measured. Values of the slope $(g)$ and $y$-intercept $(k)$ of the Model I regression between bacterial net growth rate and level of dilution are shown. Bacterial DMS consumption was determined by use of the inhibitor dimethyl disulfide (DMDS), in undiluted incubations conducted parallel to the dilution experiments. Values of $\Delta$ DMS are the mean values from 2 incubations. ns: no significant difference between incubations, $\mathrm{p} \leq 0.05$

\begin{tabular}{|c|c|c|c|c|c|}
\hline $\begin{array}{l}\text { Expt, } \\
\text { Date }\end{array}$ & $\begin{array}{l}\text { Slope of } \\
\text { regression } \\
(g \pm S E)\end{array}$ & $\begin{array}{l}y \text {-intercept of } \\
\text { regression } \\
(k \pm S E)\end{array}$ & $\begin{array}{r}\Delta \mathrm{DN} \\
\text { incubat } \\
\text { DMDS }\end{array}$ & $\begin{array}{l}\text { arallel } \\
\mathrm{M} \mathrm{S} \mathrm{h}^{-1} \text { ) } \\
\text { Control }\end{array}$ & $\begin{array}{c}\text { Consumption of DMS } \\
\text { in undiluted water } \\
\left(\mathrm{nM} \mathrm{d}^{-1}\right)\end{array}$ \\
\hline \multicolumn{6}{|c|}{ Laboratory experiment } \\
\hline 22 Oct 1997 & $1.29 \pm 0.20$ & $2.54 \pm 0.11$ & - & - & - \\
\hline $\begin{array}{l}\text { North Sea } \\
\quad 13 \text { Apr } 1998\end{array}$ & $0.65 \pm 0.12$ & $0.69 \pm 0.08$ & 2.01 & 2.02 & ns \\
\hline $\begin{array}{l}\text { Iceland Basin } \\
27 \text { Jun } 1998\end{array}$ & $0.72 \pm 0.31$ & $0.75 \pm 0.20$ & 0.25 & -0.06 & 7.42 \\
\hline $\begin{array}{c}\text { Iceland Basin } \\
4 \text { Jul } 1998\end{array}$ & $0.52 \pm 0.14$ & $0.60 \pm 0.09$ & 0.09 & -0.10 & 4.67 \\
\hline
\end{tabular}


bations in which surface waters were used as the diluent were $19 \% \mathrm{~d}^{-1}$ of the initial standing stock on the 27 June and $15 \% \mathrm{~d}^{-1}$ on 4 July (Table 3 ).

Using water from $100 \mathrm{~m}$, concentrations of DMS and DMSPd at the start of Iceland Basin incubations varied with the level of dilution (Table 4). On 27 June, DMS production occurred in all the incubations, whilst a loss of DMSPd and DMS+DMSPd occurred in all but the most dilute incubation (Table 4). A net loss of both DMS and DMSPd occurred in all the dilution incubations on 4 July (Table 4).

Bacterial abundance was higher in the experiments conducted in the Iceland Basin than southern North Sea (Table 2). In both experiments, estimates of the rates of growth of bacteria $(k)$ and the slope of the regression $(g)$ were closely matched and higher than those of the nanophytoplankton (Table 5). In all three in situ experiments, the net growth rates of bacteria exceeded those of the phytoplankton in the more dilute incubations. Although $k$ and $g$ may not strictly represent bacterial specific growth rate and mortality due to grazing (Landry 1993), they have been used to calculate the mean abundance (Frost 1972) of bacteria and a ratio of mean bacterial:mean algal concentration $(<B>:<C>)$ during each incubation (Table 6).

\section{DMS consumption}

In the North Sea incubations with DMDS added, there was no significant increase in DMS concentration compared to controls. This suggests there was negligible bacterial DMS consumption (Table 5). In contrast, in similar experiments conducted in the Iceland Basin, production of DMS was higher in incubations to which DMDS had been added compared to control incubations, suggesting an active bacterial consumption of DMS (Table 5).

\section{Algal-specific production/loss of DMS and DMSPd and grazing pressure}

The relationship between algal-specific production and the level of dilution, a proxy of grazing pressure, is shown for each experiment (Figs. 1, 2, $3 \& 4$ ). The values of the Model 1 regressions in each case are given in Table 7.
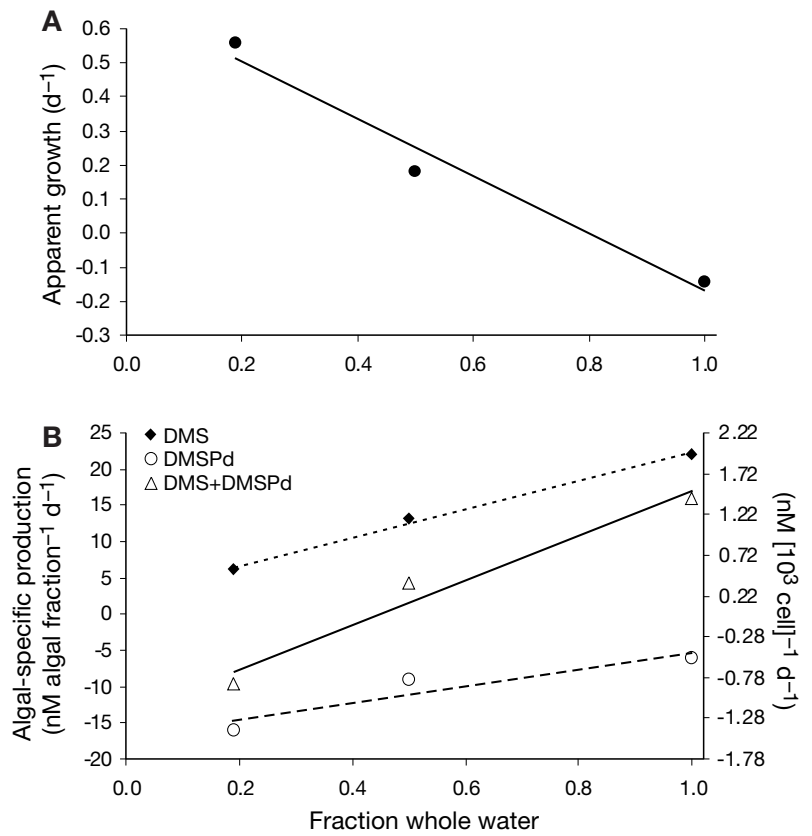

Fig. 1. Laboratory experiment. (A) Dilution plot of apparent growth of Isochrysis galbana versus level of dilution $(y=$ $-0.85 x+0.67)$; (B) relationship between algal-specific DMS, DMSPd and DMS+DMSPd production and the level of dilution. Algal-specific production was calculated from the net production of DMS, DMSPd and DMS+DMSPd normalised to the mean concentration of $I$. galbana cells during each incubation expressed as a fraction of the concentration in the undiluted incubation (fraction whole water $=1)(\langle C\rangle$ : Table 6$)$ (DMS: $y=19.4 x+2.9$; DMSPd: $y=11.5 x-16.8$; DMS+ DMSPd: $y=30.9 x-13.9)$. The $I$. galbana cell-specific rates (nM $\left[10^{6} \text { I. galbana cells }\right]^{-1} \mathrm{~d}^{-1}$ ) are shown on the secondary $y$-axis (DMS: $y=1.73 x+0.26$; DMSPd: $y=1.02 x-1.50$; DMS+DMSPd: $y=2.75 x-1.24)$. The values and significance of the linear regressions for this and all subsequent figures are given in Table 3 for the dilution plot and Table 7 for the fraction-specific DMS/DMSPd dynamics 

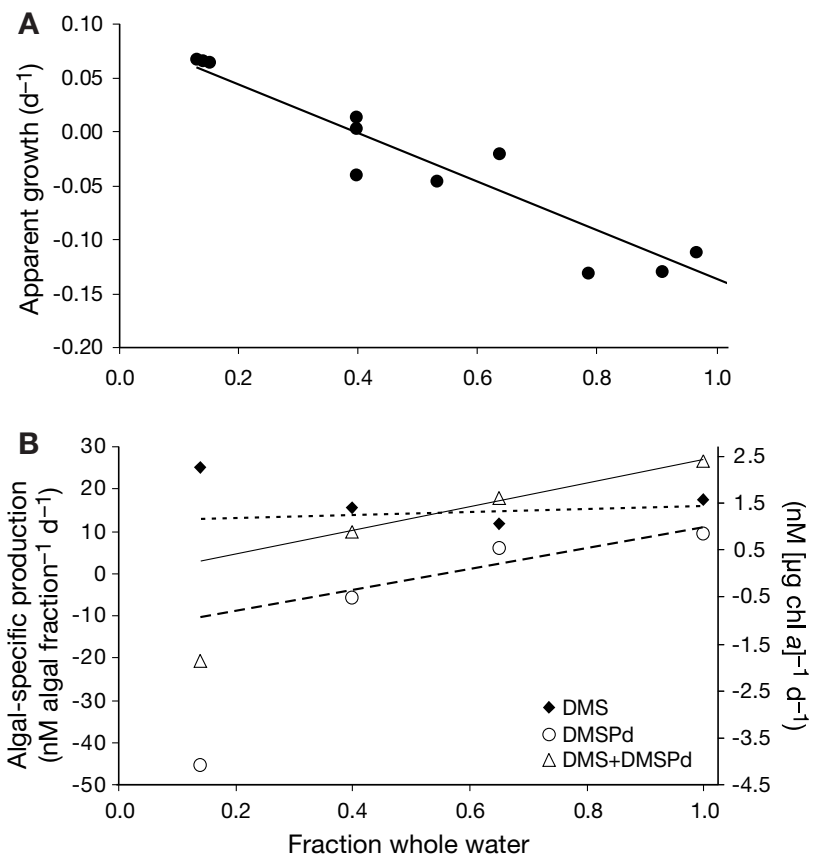

Fig. 2. North Sea, 13 April. (A) Dilution plot of apparent growth of chlorophyll a (chl a) versus level of dilution $(y=$ $-0.23 x+0.09$ ); (B) relationship between algal-specific DMS, DMSPd and DMS+DMSPd production and the level of dilution. DMS, DMSPd and DMS+DMSPd production is normalised to the mean concentration of chl a during each incubation expressed as a fraction of the concentration in the undiluted incubation $(<C>$ : Table 6$)$ (DMS: $y=3.7 x+12.4$; DMSPd: $y=24.3 x-13.4$; DMS+DMSPd: $y=28.0 x-1.0)$. The chlorophyll-specific rates (nM $[\mu \mathrm{g} \mathrm{chl} \mathrm{a}]^{-1} \mathrm{~d}^{-1}$ ) are shown on the secondary $y$-axis (DMS: $y=0.33 x+1.11$; DMSPd: $y=$ $2.18 x-1.20$; DMS+DMSPd: $y=2.52 x-0.09$ ). Note that values from the most dilute level of incubation are not included in the regression analyses of DMS, DMSPd or DMS+DMSPd dynamics (Table 7)

\section{DISCUSSION}

The aim of this research was to test the utility of the dilution technique as an approach for quantifying DMS and DMSPd production due to microzooplankton herbivory. The concentrations of DMS and DMSPd in the dilution incubations reflect the balance between a variety of production and loss processes. If grazing by microzooplankton resulted in the transformation of DMSPp to DMS/DMSPd, an increased algal-specific production of DMS/DMSPd or reduced algal-specific loss of DMS/DMSPd would be expected with increasing grazing pressure. In the same way in which mortality due to grazing can be calculated, the slope of the relationship between algal-specific production of DMS/DMSPd and level of dilution provides an estimate of the production due to grazing. The implicit assumption is that changes in production are purely the result of the variation in grazing pressure between levels of dilution.

In the laboratory experiment, the regressions between algal-specific DMS, DMSPd and DMS+DMSPd production and fraction of whole water produced positive slopes (Fig. 1, Table 7). This suggests that a significant production due to grazing of DMS (19.4 $\left.\mathrm{nM} \mathrm{d}^{-1}\right)$ and DMS+DMSPd (30.9 $\left.\mathrm{nM} \mathrm{d}^{-1}\right)$ occurred in the undiluted culture. In the North Sea experiment, production of DMS, based on the mean chlorophyll a $(<C>)$ concentration during each incubation, was not clearly related to grazing (Fig. 2). Algal-specific DMSPd production was highest in undiluted water, but showed an increasing loss in more dilute waters. When combined, algal-specific DMS+DMSPd production occurred at the 3 highest levels of grazing and a net loss of DMS+DMSPd occurred in the most dilute incubation. The regression between algal-specific DMS+DMSPd
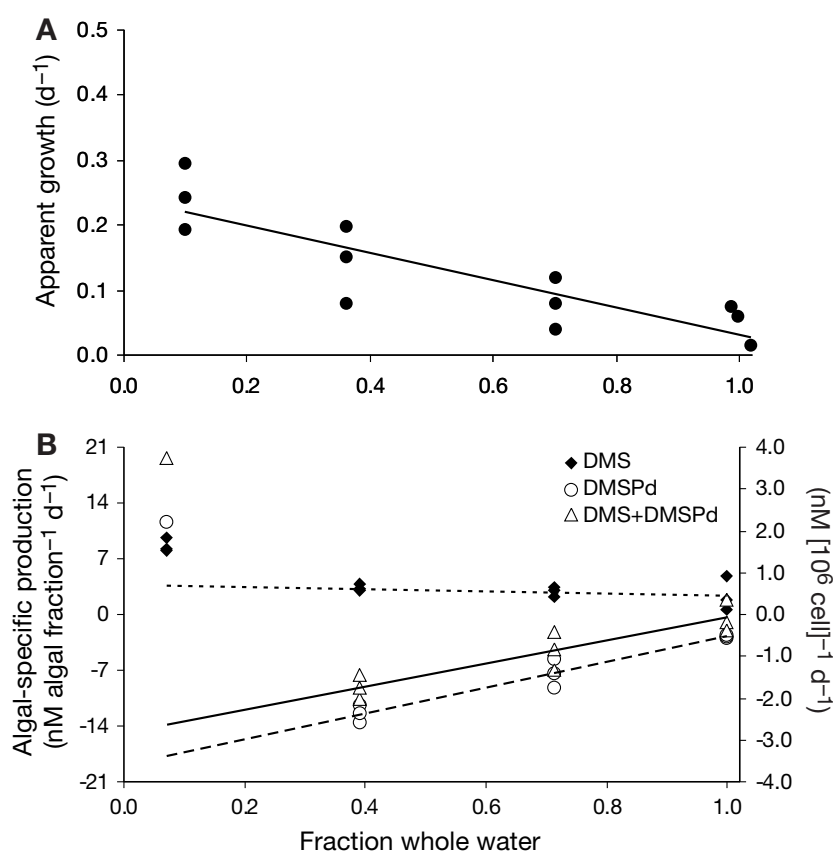

Fig. 3. Iceland Basin, 27 June. (A) Dilution plot of apparent growth of nanophytoplankton versus level of dilution $(y=$ $-0.21 x+0.24)$; (B) relationship between algal-specific DMS, DMSPd and DMS+DMSPd production and the level of dilution. DMS, DMSPd and DMS+DMSPd production is normalised to the mean concentration of nanophytoplankton cells during each incubation expressed as a fraction of the concentration in the undiluted incubation $(\langle C\rangle$, Table 6$)$ (DMS: $y=-1.5 x+3.9$; DMSPd: $y=15.9 x-18.7$; DMS+DMSPd: $y=14.4 x-14.8)$. The nanophytoplankton-specific rates (nM $\left[10^{6} \text { nanophytoplankton cells }\right]^{-1} \mathrm{~d}^{-1}$ ) are shown on the secondary $y$-axis (DMS: $y=-0.28 x+0.73$; DMSPd: $y=2.99 x-$ 3.52; DMS+DMSPd: $y=2.71 x-2.78$ ). Note that values from the most dilute level of incubation are not included in the regression analyses of DMS, DMSPd or DMS+DMSPd dynamics (Table 7) 

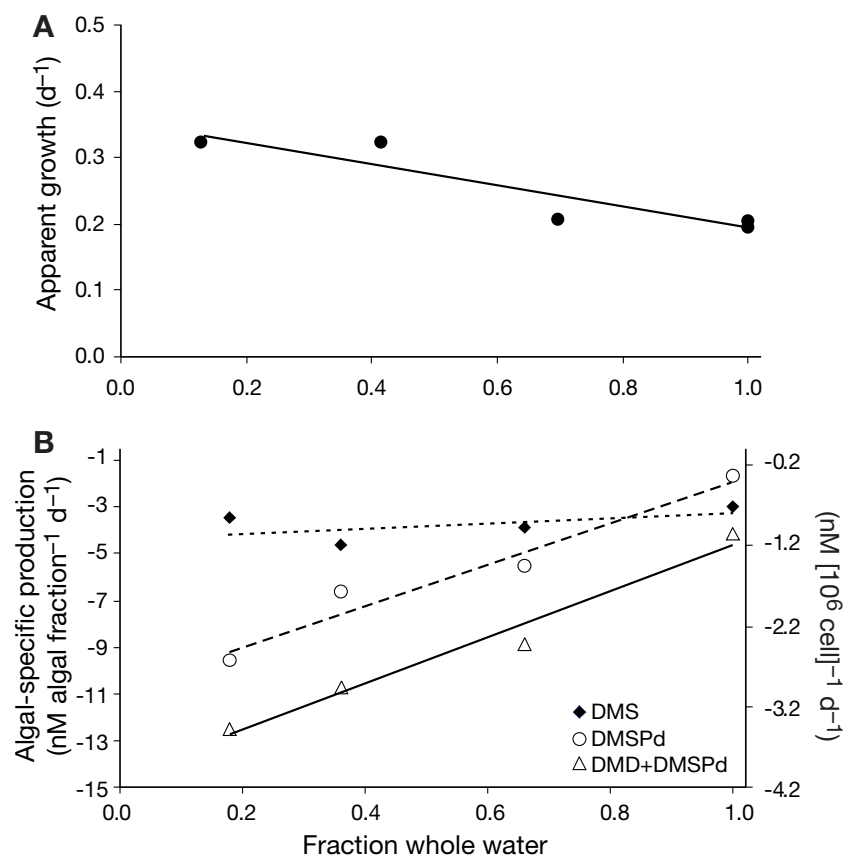

Fig. 4. Iceland Basin, 4 July. (A) Dilution plot of apparent growth of nanophytoplankton versus level of dilution $(y=$ $-0.16 x+0.35)$; (B) relationship between algal-specific DMS, DMSPd and DMS+DMSPd production and the level of dilution. DMS, DMSPd and DMS+DMSPd production is normalised to the mean concentration of nanophytoplankton cells during each incubation expressed as a fraction of the concentration in the undiluted incubation $(\langle C\rangle$ : Table 6$)$ (DMS: $y=1.0 x-3.8$; DMSPd: $y=8.9 x-10.2$; DMS+DMSPd: $y=9.9 x-14.0$ ). The nanophytoplankton-specific rates (nM $\left[10^{6} \text { nanophytoplankton cells }\right]^{-1} \mathrm{~d}^{-1}$ ) are shown on the secondary $y$-axis (DMS: $y=-0.32 x-1.20$; DMSPd: $y=2.80 x-$ 3.21; DMS+DMSPd: $y=3.12 x-4.41$ )

production and fraction of whole water is significant $(p<0.05)$ if restricted to the linear portion of the graph by omitting the data for the most dilute incubation (Fig. 2B, Table 7). This suggests a production of DMS+DMSPd due to grazing of $28.0 \mathrm{nM} \mathrm{d}^{-1}$. In the Iceland Basin on 27 June, algal-specific production of DMS and DMSPd in the most dilute incubations (fraction of whole water $=0.07$ ) was unusually high compared to the other levels of dilution (Fig. 3B). In contrast, a clear trend in algal-specific production occurred between the other 3 less dilute levels. The algal-specific DMS production was similar between the 3 levels of dilution. A significant positive slope occurred between fraction of whole water and algalspecific DMSPd and DMS+DMSPd production, indicating a production due to grazing of 15.9 and $14.4 \mathrm{nM}$ $\mathrm{d}^{-1}$, respectively (Fig. 3B, Table 7). On 4 July, a reduced algal-specific loss of DMSPd in less dilute incubations resulted in a significant positive relationship between fraction of whole water and both DMSPd and DMS+DMSPd, indicating a grazing mediated
Table 7. Relationship between algal-specific production of DMS, DMSPd and DMS+DMSPd and grazing pressure (fraction whole water). The regression lines are shown in Figs. 1, 2, $3 \& 4 . p$ is the significance of the F-ratio of the analysis of variance of each Model 1 regression

\begin{tabular}{|c|c|c|c|c|}
\hline Product & Slope & Intercept & $\mathrm{r}^{2}$ & $\mathrm{p}$ \\
\hline \multicolumn{5}{|c|}{ Laboratory experiment: 22 Oct 1997} \\
\hline DMS & $19.4 \pm 1.1$ & $2.9 \pm 0.7$ & 1.00 & 0.037 \\
\hline DMSPd & $11.5 \pm 4.5$ & $-16.8 \pm 3.0$ & 0.87 & 0.236 \\
\hline DMS+DMSPd & $30.9 \pm 5.7$ & $-13.9 \pm 3.7$ & 0.97 & 0.115 \\
\hline \multicolumn{5}{|c|}{ North Sea: 13 Apr $1998^{a}$} \\
\hline DMS & $3.7 \pm 8.8$ & $12.4 \pm 6.4$ & 0.15 & 0.746 \\
\hline DMSPd & $24.3 \pm 10.6$ & $-13.4 \pm 7.7$ & 0.84 & 0.263 \\
\hline DMS+DMSPd & $28.0 \pm 1.9$ & $-1.0 \pm 1.4$ & 1.00 & 0.043 \\
\hline \multicolumn{5}{|c|}{ Iceland Basin: 27 Jun 1998 a } \\
\hline DMS & $-1.5 \pm 1.6$ & $3.9 \pm 1.2$ & 0.11 & 0.388 \\
\hline DMSPd & $15.9 \pm 1.5$ & $-18.7 \pm 1.1$ & 0.94 & 0.000 \\
\hline DMS+DMSPd & $14.4 \pm 2.5$ & $-14.8 \pm 1.8$ & 0.83 & 0.001 \\
\hline \multicolumn{5}{|c|}{ Iceland Basin: 4 Jul 1998} \\
\hline DMS & $1.0 \pm 1.2$ & $-3.8 \pm 0.8$ & 0.28 & 0.476 \\
\hline DMSPd & $8.9 \pm 1.4$ & $-10.2 \pm 0.9$ & 0.95 & 0.024 \\
\hline DMS+DMSPd & $9.9 \pm 1.2$ & $-14.0 \pm 0.8$ & 0.97 & 0.015 \\
\hline
\end{tabular}

production of 8.9 and $9.9 \mathrm{nM} \mathrm{d}^{-1}$, respectively (Fig. 4B, Table 7). Algal-specific production of DMS was similar between levels of dilution (Fig. 4).

Current evidence suggests that the processes that control DMS concentrations in surface waters of the oceans are highly complex. At this point it is pertinent to consider to what extent other transformation, production or loss processes may have affected our estimates of grazing-mediated production of DMS, DMSPd and DMS+DMSPd. The balance between production processes other than grazing and loss processes would have to vary in proportion to algal concentration in order to correspond with the slope between fraction of whole water and algal-specific production, which we found.

\section{DMS/DMSPd production processes other than grazing}

Several processes other than grazing have been shown to cause the release of DMS/DMSPd from phytoplankton, including viral lysis (Hill et al. 1998, Malin et al. 1998) and cell autolysis or excretion, which may occur under conditions of nutrient depletion (Nguyen et al. 1988, Stefels \& van Boekel 1993). Viruses with a head size of less than $60 \mathrm{~nm}$ dominate natural aquatic populations (Bergh et al. 1989), and filters with a pore size of $0.2 \mu \mathrm{m}$ diameter are routinely used as a first step to separate viruses from other 
components of the plankton (e.g. Suttle et al. 1990). Although, viruses were not quantified, most free viruses would pass through both the GF/C filter and Gelman $0.2 \mu \mathrm{m}$ pore-size capsule filters used in our studies. Even with similar concentrations of viruses in the dilution series, the probability of specific infection of phytoplankton cells may tend to decline. However, how viral mortality will alter in a dilution series is not known and may be complex. For instance, viral-host interactions may involve lytic and/or lysogenic infection (Wilson \& Mann 1997) and latent periods are likely to vary with each taxon of phytoplankton. Another factor that can influence dilution experiments is nutrient concentration. In the North Sea experiment it is probable that phosphate was limiting phytoplankton growth, as previously observed in Dutch coastal waters during April (e.g. Peeters \& Perpezak 1990), although this was not tested. However, as phytoplankton growth rates do not appear to have varied between levels of dilution (see 'Results') we consider this not to have been significant in our experiments. Therefore, DMS/DMSPd release as a consequence of viral lysis and cell autolysis or excretion may have declined with decreasing algal concentration in each incubation, confounding estimates of grazing-mediated production.

\section{DMS/DMSPd loss processes}

A net decrease of DMS+DMSPd concentration was observed in many of the incubations (Table 3), showing that loss processes often exceed production rates. If grazing-mediated production is an important component of the production processes, the increased algalspecific loss of DMS/DMSPd in more dilute incubations and therefore at lower grazing pressures, is to be expected. However, loss processes could vary in relation to algal concentration between levels of dilution and may thereby affect estimates of grazing-mediated production. The most likely causes of DMS/DMSPd removal during incubations are bacterial metabolism (e.g. Kiene \& Bates 1990, Ledyard \& Dacey 1996), photochemical degradation of DMS (e.g. Brimblecombe \& Shooter 1986, Kieber et al. 1996) and ventilation of DMS to the headspace in incubation bottles.

In addition to cleaving DMSPd to DMS, bacteria in natural seawater are able to metabolise DMS (Kiene \& Bates 1990, Kiene \& Service 1991) and to demethylate/ demethiolate DMSPd (e.g. Taylor \& Gilchrist 1991). How these processes affected the estimates of grazingmediated DMS, DMSPd and DMS+DMSPd production depends on their rates and whether the rates varied in relation to algal concentration through the dilution series. The magnitude of DMS metabolism by bacteria in each of the experiments in natural waters is illus- trated by the incubations in which DMDS was used as an inhibitor (Table 5). The lack of a significant consumption of DMS in the North Sea experiment, in contrast to the waters from the Iceland Basin, may explain the higher net production of DMS in the North Sea (Table 3). Independent incubations carried out at the same locations and times using DMDS produced results that confirmed the low DMS consumption rates in the southern North Sea (G. Malin \& A. Hatton unpubl. data) and the significant DMS consumption in the Iceland Basin (Simó \& Pedrós-Alió 1999). No direct estimates of DMSPd metabolism by bacteria were made. However, in a similar way to the calculation of phytoplankton growth rate $(k)$ from dilution experiments, an estimate of the production/loss in the absence of grazing may be obtained from the intercept of the relationship between algal-specific production and fraction of whole water (Table 7). This parameter is an indication of the balance between the combined production processes other than grazing and the combined loss processes. In the laboratory experiment, the regression analyses suggest a loss of DMSPd of $16.8 \mathrm{nM} \mathrm{d}^{-1}$ and a loss of DMS+DMSPd of $13.9 \mathrm{nM} \mathrm{d}^{-1}$ in the absence of grazing. Although, note that values of $p$ for the regressions are $>0.05$ in both cases. The intercept of the regression of algal-specific production of DMS and fraction of whole water is $2.9 \mathrm{nM} \mathrm{d}^{-1}$ (Table 7), and no direct estimate of DMS consumption was made. On 13 April, the relationships between algal-specific DMS and DMSPd production were not significant and no estimate of the production/loss in the absence of grazing can be made for the individual compounds. However, when combined, the regression based on production rates at the 3 highest levels of fraction of whole water indicate a loss of $1.0 \mathrm{nM} \mathrm{d}^{-1}$ of DMS+ DMSPd (Table 7). On 27 June, the loss rate of DMS+ DMSPd in the absence of grazing was $14.8 \mathrm{nM} \mathrm{d}^{-1}$. If the DMS consumption rate of $7.4 \mathrm{nM} \mathrm{d}^{-1}$ measured from the DMDS incubations is taken into account, a loss of DMSPd by processes other than cleavage to DMS amounts to $7.4 \mathrm{nM} \mathrm{d}^{-1}$ in the absence of grazing. Similarly, on 4 July a loss of DMSPd by processes other than cleavage to DMS amounts to $5.2 \mathrm{nM} \mathrm{d}^{-1}$ in the absence of grazing. These values of net DMSPd loss in the absence of grazing are in the lower range of removal rates of DMSPd estimated using a kinetic approach in waters from Vineyard Sound and the Sargasso Sea (1.4 to $16.8 \mathrm{nM} \mathrm{d}^{-1}$ ) (Ledyard \& Dacey 1996), when glycine betaine was used as an inhibitor of DMSPd consumption (4 to $28 \mathrm{nM} \mathrm{d}^{-1}$ ) (Kiene \& Gerard 1995) and by using additions of ${ }^{35} \mathrm{~S}-\mathrm{DMSPd}$ (3 to $129 \mathrm{nM} \mathrm{d}^{-1}$ ) in the Gulf of Mexico (Kiene \& Linn 2000).

As stated previously, variations in the relative mean concentrations of bacteria and algae $(\langle B\rangle:\langle C\rangle$ : Table 6$)$ between levels of dilution provide an indication of the 
influence that bacteria may have on algal-specific rates of DMS/DMSPd consumption. The greatest variation in the $\langle B\rangle:\langle C>$ ratio between levels of dilution occurred in the laboratory experiment, with a 3 -fold increase in the proportion of bacteria at fraction of whole water $=0.19$ compared to fraction of whole water $=1.00$ (Table 6). In contrast, in the experiments in natural waters $\langle B\rangle:\langle C\rangle$ remained more constant, suggesting little variation in bacterial influence on algal-specific loss rates. However, how rapidly the composition of bacterial communities change in response to dilution and how bacteria might respond to increasing availability of DMS and DMSPd as a result of decreased competition are uncertain.

There is evidence that bacteria may acquire DMSPd without immediately degrading it (Diaz et al. 1992, Wolfe 1996), thereby potentially transforming DMSP from the dissolved to particulate phase. Furthermore, it is possible that bacterial DMSP may be degraded or transferred to higher trophic levels by bacterivores (Wolfe 1996). It remains unclear how important these 2 processes are in natural waters and how they may have affected estimates of DMS/DMSPd production in the present study.

DMS photolysis has been shown to be an important removal pathway for DMS (Brimblecombe \& Shooter 1986, Kieber et al. 1996), and the volatile nature of DMS means that it may be lost to the headspace of incubation vessels during experiments. Although efforts were made to minimise the size of the headspace in incubation bottles, DMS may have been lost from solution to the small headspace (10 to $20 \mathrm{ml}$ ) that did occur, possibly resulting in a slight underestimation of DMS production. In addition, the incubations of natural water in the present study were carried out in polycarbonate Nalgene bottles under an acrylic screen and two sheets of Perspex. Under these incubation conditions, DMS removal due to photolysis may have occurred, again leading to an underestimate of DMS production. In the equatorial Pacific, the relationship between rate of photolysis and DMS concentration was linear at less than approximately $50 \mathrm{nM}$ (Kieber et al. 1996). In the present study, the concentration of DMS in the incubations using natural waters was generally lower than $50 \mathrm{nM}$. Therefore, DMS loss due to photolysis may have been a constant proportion of the DMS production throughout the dilution series and, if so, would have had little affect on estimates of algalspecific DMS and DMS+DMSPd production. Concurrent measurements of DMSO production could be used to provide an indication of the relative loss of DMS due to photolysis through the dilution series.

In summary, if the assumptions of the dilution technique that phytoplankton growth is density-independent and that phytoplankton mortality is density de- pendent (Landry \& Hassett 1982) are met, then the most serious sources of error in estimates of DMS/ DMSPd production due to grazing are most likely to stem from bacterial metabolism and possibly viral lysis. In general, rates of biological DMSPd turnover approximate 1 to 10 -fold ambient concentrations $\mathrm{d}^{-1}$ (reviewed in Kiene et al. 2000), and may be higher than those of the biological turnover of DMS at approximately 0.3 to 3-fold ambient concentrations $\mathrm{d}^{-1}$ (Ledyard \& Dacey 1996, Simó \& Pedrós-Alió 1999). Nevertheless, the overriding consequence of the dilution technique is to produce a gradient of grazing pressure. For instance, in the experiment carried out on 27 June, the proportion of total chlorophyll $a(<C>)$ that was grazed varied almost 10 -fold, from $3 \% \mathrm{~d}^{-1}$ at a fraction of whole water of 0.14 to $23 \% \mathrm{~d}^{-1}$ in undiluted water, assuming density-dependent grazing mortality. In comparison, relative bacterial abundance $(\langle B\rangle:\langle C\rangle)$ varied from only 47 to $39 \times 10^{6}$ bacteria $\mu \mathrm{g}$ chlorophyll $a^{-1}$ at the same levels of dilution (Table 6), suggesting that large changes in bacterial metabolism or composition would be required to substantially affect estimates of grazing-mediated production of DMS/DMSPd.

\section{Significance and controls of grazing production of DMS/DMSPd}

Despite the potential problems, the present study is the first to provide direct estimates of microzooplankton-mediated production of the dissolved pool of DMS+DMSPd in natural waters. The estimates of grazing-mediated production of DMS+DMSPd in the laboratory experiment and on 13 April, 27 June and 4 July (Table 7) were equivalent to $37,130,27$ and $24 \% \mathrm{~d}^{-1}$ of the ambient DMS+DMSPd concentrations, respectively. This represents a conversion to DMS+DMSPd of $19,14,15$ and $9 \% \mathrm{~d}^{-1}$ of the DMSPp standing stock. In the laboratory experiment, it is possible to estimate a conversion of $33 \%$ of ingested DMSPp to DMS+DMSPd by Oxyrrhis marina if it is assumed that all the DMSPp was contained in the cells of Isochrysis galbana. Interestingly, estimates of microzooplankton-specific production of DMS+DMSPd in natural waters are similar between the 3 experiments at $0.78,0.65$ and $0.39 \mathrm{nM} \mathrm{S}$

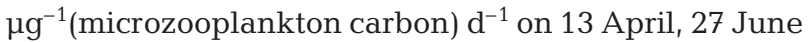
and 4 July, respectively. If these values are representative, then microzooplankton grazing appears to be an important pathway in the production of DMS+DMSPd.

A combination of factors is expected to control the extent of DMS+DMSPd production due to grazing. Most significant is the composition of the phytoplankton. The experiments in the present study were conducted in waters containing relatively high but not exceptional concentrations of DMSPp (93 to 202 nM; 
Table 2), indicative of DMSP-rich phytoplankton. Microzooplankton populations are generally diverse and are likely to employ a wide variety of feeding, digestion, assimilation and excretion processes that may all affect the extent of conversion of DMSPp to DMS+DMSPd. For instance, the duration of the digestive cycle, sequence of food vacuole contraction, expansion, acidification and subsequent rise in $\mathrm{pH}$ varies between ciliates (Nilsson 1977, Fok et al. 1982). Differences in composition of dissolved organic carbon produced by the ciliate grazer Strombidinopsis acuminatum and dinoflagellate Oxyrrhis marina when fed the same phytoplankton prey is evidence of interspecific variation in digestion, assimilation or excretion processes between the 2 species (Strom et al. 1997). The heterotrophic dinoflagellate Crypthecodinium (Gyrodinium) cohnii possesses DMSP lyase (Kadota \& Ishida 1968), whereas O. marina appears to have no lyase activity (M. Steinke pers. comm.). Hence, pelagic microzooplankton may vary in their ability to cleave DMSP themselves. The extent of cleavage of DMSP to DMS during digestion may affect the level of DMS(P) assimilation by microzooplankton. Variations in the in vitro activity of DMSP lyase enzymes between several strains of Emiliania huxleyi is thought to explain differences in the level of DMS production during grazing by O. marina (Wolfe et al. 1997). The grazing-mediated production rates of DMS+DMSPd in the present study indicate that microzooplankton do graze on DMSPprich phytoplankton in natural waters. However, it remains to be demonstrated whether microzooplankton select phytoplankton prey on the basis of their DMSPp concentration and/or DMSP lyase activity in the natural situation.

\section{Conclusion}

Recently, Wolfe et al (2000) concluded that the dilution approach is poorly suited to assessing the impact of grazing on dissolved sulphur pools because of rapid microbial consumption and the artifactual release of DMSP and DMS during filtration. In contrast, the present study demonstrates that there is merit in this approach. In waters where microzooplankton grazing is significant, the dilution method provides estimates of the contribution of microzooplankton grazing to the dissolved pool of DMS+DMSP. Further refinement of the method is required to fully account for the competing production and loss processes of DMS and DMSPd that occur during long-term dilution incubations, such as bacterial metabolism and viral lysis. In addition, further studies are required to understand how the composition of both the phytoplankton and microzooplankton affect the extent of grazing-mediated trans- formation of DMSPp to DMSPd and DMS. Integrated studies are needed to elucidate the fate of the dissolved DMSP and DMS produced by microzooplankton herbivory and to ascertain the relative significance of the variety of pathways that result in the release of phytoplankton DMSPp. Such integrated studies will be demanding but necessary if we are to understand the multiplicity of factors that influence DMS production in the sea.

Acknowledgements. We wish to thank J. Stefels and P. Liss for cruise leadership aboard RV 'Pelagia' (cruise 64PE116) and the RRS 'Discovery' (Cruise D234), and acknowledge the help of the officers and crew on board. We also thank A. Hatton, S. Turner, S. Belviso, R. Simó and M. Steinke for advice on DMS measurements and experimental design and G.Tarran for advice on $\mathrm{AFC}$. The comments of 3 referees and guidance of $\mathrm{J}$. Dolan are appreciated and helped to improve the manuscript. This is contribution No. 215 of the European Union European Land-Ocean Interaction Studies (ELOISE) Programme in the framework of the Entangled Sulfur and Carbon Cycles in Phaeocystis dominated Ecosystems (ESCAPE) project. It is also contribution ACP141 of the Atmospheric Chemistry Studies in the Oceanic Environment (ACSOE) programme of the Natural Environment Research Council (NERC). The research was supported by funding through the ESCAPE programme (MAS3-CT96-0050), the Defence Evaluation and Research Agency (DERA/SESS/C21.10.2) and from NERC Grants [GR3/10956 and GT5/98/8/MS]. The research formed part of the DYME programme of Plymouth Marine Laboratory.

\section{LITERATURE CITED}

Andersen T, Schartau AKL, Paasche E (1991) Quantifying external and internal nitrogen and phosphorus pools, as well as nitrogen and phosphorus supplied through remineralisation, in coastal marine plankton by means of a dilution technique. Mar Ecol Prog Ser 69:67-80

Andreae MO (1990) Ocean-atmosphere interactions in the global biogeochemical sulfur cycle. Mar Chem 30:1-29

Bacic MK, Yoch DC (1998) In vivo characterisation of dimethylsulfoniopropionate lyase in the fungus Fusarium lateritium. Appl Environ Microbiol 64:106-111

Barnard WR, Andreae MO, Iverson RL (1984) Dimethylsulfide and Phaeocystis pouchetii in the southeastern Bering Sea. Cont Shelf Res 3:103-113

Bates TS, Cline JD, Gammon RH, Kelly-Hansen SR (1987) Seasonal variations in the flux of oceanic dimethylsulfide to the atmosphere. J Geophys Res 92:2930-2938

Belviso S, Kim SK, Rassoulzadegan F, Krajka B, Nguyen BC, Mihalopoulos N, Buat-Menard P (1990) Production of dimethylsulphonium propionate (DMSP) and dimethyl sulfide (DMS) by a microbial food web. Limnol Oceanogr 8: 1810-1821

Bergh O, Borsheim KY, Bratbak G, Hedal M (1989) High abundance of viruses found in aquatic environments. Nature 340:467-468

Brimblecombe P, Shooter D (1986) Photo-oxidation of dimethyl sulfide in aqueous solution. Mar Chem 19:343-354

Burkill PH, Edwards ES, John AWG, Sleigh MA (1993) Microzooplankton and their herbivorous activity in the northeastern Atlantic Ocean. Deep-Sea Res 40:479-493

Charlson RJ, Lovelock JE, Andreae MO, Warren SG (1987) 
Oceanic phytoplankton, atmospheric sulfur, cloud albedo and climate. Nature 326:655-661

Chavez FP, Buck KR, Coale KR, Martin JH, DiTullio GR, Welschmeyer NA, Jacobson AC, Barber RT (1991) Growth rates, grazing, sinking, and iron limitation of equatorial Pacific phytoplankton. Limnol Oceanogr 36:1816-1833

Christaki U, Belviso S, Dolan JR, Corn M (1996) Assessment of the role of copepods and ciliates in the release to solution of particulate DMSP. Mar Ecol Prog Ser 141:119-127

Dacey JWH, Wakeham SG (1986) Oceanic dimethylsulfide: production during zooplankton grazing on phytoplankton. Science 233:1314-1316

Daly KL, DiTullio GR (1996) Particulate dimethylsulfoniopropionate removal and dimethylsulfide production by zooplankton in the Southern Ocean. In: Kiene RP, Visscher PT, Keller MD, Kirst GO (eds) Biological and environmental chemistry of DMSP and related sulfonium compounds. Plenum Press, New York, p 223-238

de Souza MP, Yoch DC (1995) Purification and characterisation of DMSP lyase from an Alcaligenes-like dimethylsulfide-producing marine isolate. Appl Environ Microbiol 61: 21-26

de Souza MP, Chen YP, Yoch DC (1996) Dimethylsulfoniopropionate lyase from the marine macroalga Ulva curvata: purification and characterisation of the enzyme. Planta 199:433-438

Diaz MR, Visscher PT, Taylor BF (1992) Metabolism of dimethylsulfoniopropionate and glycine betaine by a marine bacterium. FEMS Microbiol Lett 96:61-66

Dolan JR, Gallegos CL, Moigis A (2000) Dilution effects on microzooplankton in dilution grazing experiments. Mar Ecol Prog Ser 200:127-139

Evans GT, Paranjape MA (1992) Precision of estimates of phytoplankton growth and microzooplankton grazing when the functional response of grazers may be nonlinear. Mar Ecol Prog Ser 80:285-290

Fok AK, Lee Y, Allen RD (1982) The correlation of digestive vacuole $\mathrm{pH}$ and size with the digestive cycle in Paramecium caudatum. J Protozool 29:409-414

Frost BW (1972) Effects of size and concentration of food particles on the feeding behaviour of the marine planktonic copepod Calanus pacificus. Limnol Oceanogr 17:805-815

Gallegos CL (1989) Microzooplankton grazing on phytoplankton in Rhode River, Maryland: non-linear feeding kinetics. Mar Ecol Prog Ser 57:23-33

Gifford DJ (1988) Impact of grazing by microzooplankton in the northwest arm of Halifax Harbour, Nova Scotia. Mar Ecol Prog Ser 47:249-258

Goldman JC, Dennett MR (1985) Susceptibility of some marine phytoplankton species to cell breakage during filtration and post-filtration rinsing. J Exp Mar Biol Ecol 86:47-58

Guillard RRL, Ryther JH (1962) Studies of marine planktonic diatoms. I. Cyclotella nana Hustedt and Detonula confervacea (Cleve) Gram. Can J Microbiol 8:229-239

Hill RW, White BA, Cotrell MT, Dacey JWH (1998) Virusmediated total release of dimethylsulfoniopropionate from marine phytoplankton: a potential climate process. Aquat Microb Ecol 14:1-6

Holligan PM, Turner SM, Liss PS (1987) Measurement of dimethyl sulphide in frontal regions. Cont Shelf Res 7: 213-224

Holligan PM, Fernandez E, Aiken J, Balsh WM, Boyd P, Burkill PH, Finch M, Groom SB, Malin G, Muller K, Purdie DA, Robinson C, Trees CC, Turner SM, van der Wal P (1993) A biogeographic study of the coccolithophore, Emilania huxleyi, in the North Atlantic. Global Biogeochem Cycles 7:879-900
Kadota H, Ishida Y (1968) Effects of salt on enzymatical production of dimethyl sulfide from Gyrodinium cohnii. Bull Jpn Soc Sci Fish 34:512-518

Keller MD, Bellows WK, Guillard RRL (1989) A survey of dimethylsulfide production in 12 classes of marine phytoplankton. ACS (Am Chem Soc) Symp Ser 393:167-182

Kieber DJ, Jiao J, Kiene RP, Bates TS (1996) Impact of dimethylsulfide photochemistry on methyl sulfur cycling in the equatorial Pacific Ocean. J Geophys Res 101 (C2): 3715-3722

Kiene RP, Bates TS (1990) Biological removal of dimethyl sulfide from sea water. Nature 345:702-705

Kiene RP, Gerard G (1995) Evaluation of glycine betaine as an inhibitor of dissolved dimethylsulfoniopropionate degradation in coastal waters. Mar Ecol Prog Ser 128:121-131

Kiene RP, Linn LJ (2000) Distribution and turnover of dissolved DMSP and its relationship with bacterial production and dimethylsulphide in the Gulf of Mexico. Limnol Oceanogr 45:849-861

Kiene RP, Service SK (1991) Decomposition of dissolved DMSP and DMS in estuarine waters: dependence on temperature and substrate concentration. Mar Ecol Prog Ser 76:1-11

Kiene RP, Linn LJ, Bruton JA (2000) New and important roles for DMSP in marine microbial communities. J Sea Res 43: 209-224

Kwint RLJ, Irigoien X, Kramer KJM (1996) Copepods and DMSP. In: Kiene RP, Visscher PT, Keller MD, Kirst GO (eds) Biological and environmental chemistry of DMSP and related sulfonium compounds. Plenum Press, New York, p 239-252

Landry MR (1993) Estimating rates of growth and grazing mortality of phytoplankton by the dilution method. In: Kemp PF, Sherr BF, Cole JJ (eds) Handbook of methods in aquatic microbial ecology. Lewis, Boca Raton, FL, p $715-722$

Landry MR, Hassett RP (1982) Estimating the grazing impact of marine microzooplankton. Mar Biol 67:283-288

Landry MR, Kirshtein JC, Constantinou J (1995) A refined dilution technique for measuring the community grazing impact of microzooplankton, with experimental tests in the central equatorial Pacific. Mar Ecol Prog Ser 120: $53-63$

Leck C, Larrson U, Bagander LE, Johansson S, Hajdu S (1990) Dimethyl sulfide in the Baltic Sea: annual variability in relation to biological activity. J Geophys Res 95:3353-3363

Ledyard KM, Dacey JWH (1996) Microbial cycling of DMSP and DMS in coastal and oligotrophic seawater. Limnol Oceanogr 41:33-40

Lessard EJ (1991) The trophic role of heterotrophic dinoflagellates in diverse marine environments. Mar Microb Food Webs 5:49-58

Lovelock JE, Maggs RJ, Rasmussen RA (1972) Atmospheric dimethyl sulphide and the natural sulphur cycle. Nature 237:452-453

Malin G, Turner SM, Liss PS, Holligan PM, Harbour DS (1993) Dimethyl sulfide and dimethylsulfoniopropionate in the Northeast Atlantic during the summer coccolithophore bloom. Deep-Sea Res 40:1487-1508

Malin G, Liss PS, Turner SM (1994) Dimethyl sulphide: production and atmospheric consequences. Syst Assoc Spec Vol 51, p 303-320

Malin G, Wilson WH, Bratbak G, Liss PS, Mann NH (1998) Elevated production of dimethyl sulfide resulting from viral infection of cultures of Phaeocystis pouchetii. Limnol Oceanogr 43:1389-1393

Marie D, Partensky F, Jacquet S, Vaulot D (1997) Enumera- 
tion and cell cycle analysis of natural populations of marine picoplankton by flow cytometry using the nucleic acid stain SYBR B Green I. Appl Environ Microbiol 63: 186-193

Matrai PA, Keller MD (1993) Dimethylsulfide in a large-scale coccolithophore bloom in the Gulf of Maine. Cont Shelf Res 13:831-843

Neuer S, Franks PJS (1993) Determination of ammonium uptake and regeneration rates using the seawater dilution method. Mar Biol 116:497-505

Nguyen BC, Belviso S, Mihalopoulos N (1988) Dimethyl sulfide production during natural phytoplanktonic blooms. Mar Chem 24:133-141

Nilsson JR (1977) On food vacuoles in Tetrahymena pyriformis GL. J Protozool 24:502-507

Peeters JCH, Perpezak L (1990) Nutrient limitation in the North Sea: a bioassay approach. Neth J Sea Res 26:61-73

Putt M, Stoecker DK (1989) An experimentally determined carbon:volume ratio for marine 'oligotrichous' ciliates from estuarine and coastal waters. Limnol Oceanogr 34: 1097-1103

Sieburth J McN (1960) Acrylic acid, an 'antibiotic' principal in Phaeocystis blooms in Antarctic waters. Science 132: 676-677

Simó R, Pedrós-Alió C (1999) Short-term variability in the open ocean cycle of dimethylsulfide. Global Biogeochem Cycles 13:1173-1181

Sokal RR, Rohlf FJ (1981) The principles and practise of statistics in biological research, 2nd edn. WH Freeman \& Company, New York

Stefels J, Dijkhuizen L (1996) Characteristics of DMSP-lyase in Phaeocystis sp. (Prymnesiophyceae). Mar Ecol Prog Ser 131:307-313

Stefels J, van Boekel WHM (1993) Production of DMS from dissolved DMSP in axenic cultures of the marine phytoplankton species Phaeocystis sp. Mar Ecol Prog Ser 97:11-18

Stefels J, Dijkhuizen L, Gieskes WWC (1995) DMSP-lyase activity in a spring phytoplankton bloom off the Dutch coast, related to Phaeocystis sp. abundance. Mar Ecol Prog Ser 123:235-243

Steinke M, Wolfe GV, Kirst GO (1998) Partial characterisation of dimethylsulfoniopropionate (DMSP) lyase isozymes in six strains of Emiliania huxleyi. Mar Ecol Prog Ser 175: $215-225$

Strom SL, Benner R, Ziegler S, Dagg MJ (1997) Planktonic grazers are a potentially important source of marine dissolved organic carbon. Limnol Oceanogr 42:1364-1374

Suttle CA, Chan AM, Cottrell MT (1990) Infection of phytoplankton by viruses and reduction of primary productivity. Nature 347:467-469

Taylor BF, Gilchrist DC (1991) New routes for the aerobic

Editorial responsibility: John Dolan,

Villefranche-sur-Mer, France biodegradation of dimethylsulfoniopropionate. Appl Environ Microbiol 57:3581-3584

Turner SM, Malin G, Liss PS, Harbour DS, Holligan PM (1988) The seasonal variation of dimethyl sulphide and dimethylsulfoniopropionate in nearshore waters. Limnol Oceanogr 33:364-375

Turner SM, Malin G, Bagander LE, Leck C (1990) Interlaboratory calibration and sample analysis of dimethyl sulfide in water. Mar Chem 29:47-62

Turner SM, Malin G, Nightingale PD, Liss PS (1996) Seasonal variation of dimethyl sulfide in the North Sea and an assessment of fluxes to the atmosphere. Mar Chem 54: $245-262$

Utermöhl H (1958) Zur Vervollkommnung der quantitativen Phytoplankton-Methodik. Mitt Int Ver Theot Angew Limnol 9:1-38

van Duyl FC, Gieskes WWC, Kop AJ, Lewis WE (1998) Biological control of short-term variations in the concentration of DMSP and DMS during a Phaeocystis spring bloom. J Sea Res 40:221-231

Verity PG, Stoecker DK, Sieracki ME, Nelson JR (1996) Microzooplankton grazing of primary production at $140^{\circ} \mathrm{W}$ in the equatorial Pacific. Deep-Sea Res 43:1227-1255

Wilson WH, Mann NH (1997) Lysogenic and lytic viral production in marine microbial communities. Aquat Microb Ecol 13:95-100

Wolfe GV (1996) Accumulation of dissolved DMSP by marine bacteria and its degradation via bacterivory. In: Kiene RP, Visscher PT, Keller MD, Kirst GO (eds) Biological and environmental chemistry of DMSP and related sulfonium compounds. Plenum Press, New York, p 277-292

Wolfe GV, Kiene RP (1993) Effects of methylated, organic, and inorganic substrates on microbial consumption of dimethyl sulfide in estuarine waters. Appl Environ Microbiol 59:2723-2726

Wolfe GV, Steinke M (1996) Grazing-activated production of dimethyl sulfide (DMS) by two clones of Emiliania huxleyi. Limnol Oceanogr 41:1151-1160

Wolfe GV, Sherr EB, Sherr BF (1994) Release and consumption of DMSP from Emiliania huxleyi during grazing by Oxyrrhis marina. Mar Ecol Prog Ser 111:111-119

Wolfe GV, Steinke M, Kirst GO (1997) Grazing-activated chemical defense in a unicellular marine alga. Nature 387:894-897

Wolfe GV, Levasseur M, Cantin G, Michaud S (2000) DMSP and DMS dynamics and microzooplankton grazing in the Labrador Sea: application of the dilution technique. DeepSea Res 47:2243-2264

Zubkov MV, Sleigh MA, Tarran GA, Burkill PH, Leakey RJG (1998) Picoplanktonic community structure on an Atlantic transect from $50^{\circ} \mathrm{N}$ to $50^{\circ} \mathrm{S}$. Deep-Sea Res 45:1339-1355

Submitted: June 20, 2000; Accepted: November 27, 2000

Proofs received from author(s): January 23, 2001 